\title{
REDESCRIPTION OF THE SIBLING SPECIES PLESIONIKA ACANTHONOTUS (SMITH, 1882) AND PLESIONIKA HOLTHUISI CROSNIER \& FOREST, 1968 (CARIDEA, PANDALIDAE)
}

\author{
IRENE AZEVEDO CARDOSO \\ Museu Nacional / UFRJ, Depto. Invertebrados, Setor de Carcinologia, Quinta da Boa Vista, 20940-040 - Rio de Janeiro - RJ, Brazil. email: \\ irenecardoso@mn.ufr.j.br
}

\section{ABSTRACT}

The Brazilian expedition REVIZEE Central - Fishery collected samples from the southwestern Atlantic coast, between depths of 200 and $2200 \mathrm{~m}$. This expedition sampled two very similar species of Plesionika Bate, 1888: Plesionika acanthonotus (Smith, 1882) and Plesionika holthuisi Crosnier \& Forest, 1968. These sibling species differs in the rostrum length, eyes size, length of third maxilliped, and number of stout setae on third and fourth pereopods. Some specimens can be clearly identified but in many specimens this identification becomes very problematic once these characters appear in intermediate stages between both species. The Brazilian material of these two species was redescribed and compared with the material deposited on Muséum National d'Histoire Naturelle collection. Besides that, a discussion about the relations and similarities of these species was done.

KEY WORDS: Caridea - Atlantic - Plesionika holthuisi - Plesionika acanthonotus - systematics

RESUMO

REDESCRIÇÃO DAS ESPÉCIES PRÓXIMAS PLESIONIKA ACANTHONOTUS (SMITH, 1882) E PLESIONIKA HOLTHUISI CROSNIER \& FOREST, 1968 (CARIDEA, PANDALIDAE)

A expedição brasileira REVIZEE Central - Pesca coletou amostras do sudoeste do oceano Atlântico, entre profundidades de 200 até $2200 \mathrm{~m}$. Esta expedição amostrou duas espécies bastante próximas de Plesionika Bate, 1888: Plesionika acanthonotus (Smith, 1882) e Plesionika holthuisi Crosnier \& Forest, 1968. Estas espécies diferem no comprimento do rostro, tamanho do olho, comprimento do terceiro maxilípede e número de cerdas robustas no terceiro e quarto pereópodos. Alguns espécimes podem ser claramente identificados, mas em vários espécimes esta identificação torna-se problemática uma vez que estes caracteres aparecem em estágios intermediários entre as duas espécies. O material brasileiro destas duas espécies foi redescrito e comparado com o material depositado na coleção do Muséum National d'Histoire Naturelle além disto, foi elaborada uma discussão sobre as relações e as similaridades entre estas espécies.

PALAVRAS-CHAVE: Caridea - Atlântico - Plesionika holthuisi - Plesionika acanthonotus sistemática

\section{INTRODUCTION}

The Infraorder Caridea Dana, 1852 includes 35 families (Martin \& Davis 2001). Pandalidae was first defined by Haworth (1825) and presently includes 19 genera according Chace's (1985) classification.

From the Brazilian coast, of the 92 Plesionika species, six are recorded: Plesionika acanthonotus (Smith, 1882); P. edwardsii (Brandt, 1851); P. ensis (A. Milne Edwards, 1881); P. longicauda (Rathbun, 1901); P. martia (A. Milne Edwards, 1883) and P. miles (A. Milne Edwards, 1883) (Ramos-Porto \& Coelho 1998; Cabral et al. 2000; Viana et al. 2007; Cardoso 2009).

The present work describes and figures two sibling species: Plesionika holthuisi that was first defined by Crosnier \& Forest (1968) in a well detailed diagnosis. In this work (Crosnier \& Forest 1968), and in a posterior one (Crosnier \& Forest 1973), these authors present the similarities and differences between $P$. holthuisi and her closest related species $P$. acanthonotus. According them P. holthuisi can be distinguished from $P$. acanthonotus in having: longer rostrum, overreaching scaphocerite; larger eyes; shorter third maxilliped; third pereopod with six or seven stout setae on merus, and fourth pereopod with subdistal stout setae on merus.

Observing the Brazilian material however, many specimens with characters in intermediate stages between the two species were observed. Cruz \& Fransen (2004) also observed these intermediate stages. The analysis of the types of $P$. hothuisi and specimens of $P$. acanthonotus deposited on the Crustacea collection of Muséum National d'Histoire Naturelle (MNHN-Paris) was fundamental for the correct identification of the Brazilian material. Comparing the Brazilian material with the type series of $P$. holthuisi and specimens of $P$. acanthonotus the differences between these species were founded easier. Even the specimens with characters in intermediate stages always were closest to one species than to another, mainly according the rostrum morphology and size.

All the measurements presented are of the carapace length, taken from the rostrum base to the carapace end. The nomenclature of the cephalic structures followed that of Mclaughlin (1980) and the setae nomenclature used was that presented by Watling (1989) and Garm (2004). 


\section{MATERIAL AND METHODS}

The specimens of this study were collected during the oceanographic program REVIZEE Central - Fishery. Between June and July of 2000 N.O. Thalassa sampled in the continental shelf and slope of the Central Brazilian coast (from $11^{\circ} \mathrm{S}$-Real river estuary, Bahia to $22^{\circ} \mathrm{S}$ - Cabo de São Tomé, Rio de Janeiro) in depths ranging from 200 to $2000 \mathrm{~m}$. Two net types were used in these trawls: ARROW $(47.4 \mathrm{~m}$
X 26.8m) and GOV (Great Opening Vertical). A total of 58 tows were done. The samples are deposited in the Collection of Crustacea of the Museu Nacional, Rio de Janeiro (MNRJ).

For comparison, the type series of $P$. hothuisi and specimens of $P$. acanthonotus deposited on the Crustacea collection of Muséum National d'Histoire Naturelle (MNHN-Paris) were examined and some diagnostic features were figured.

\section{RESULTS}

\section{Systematics}

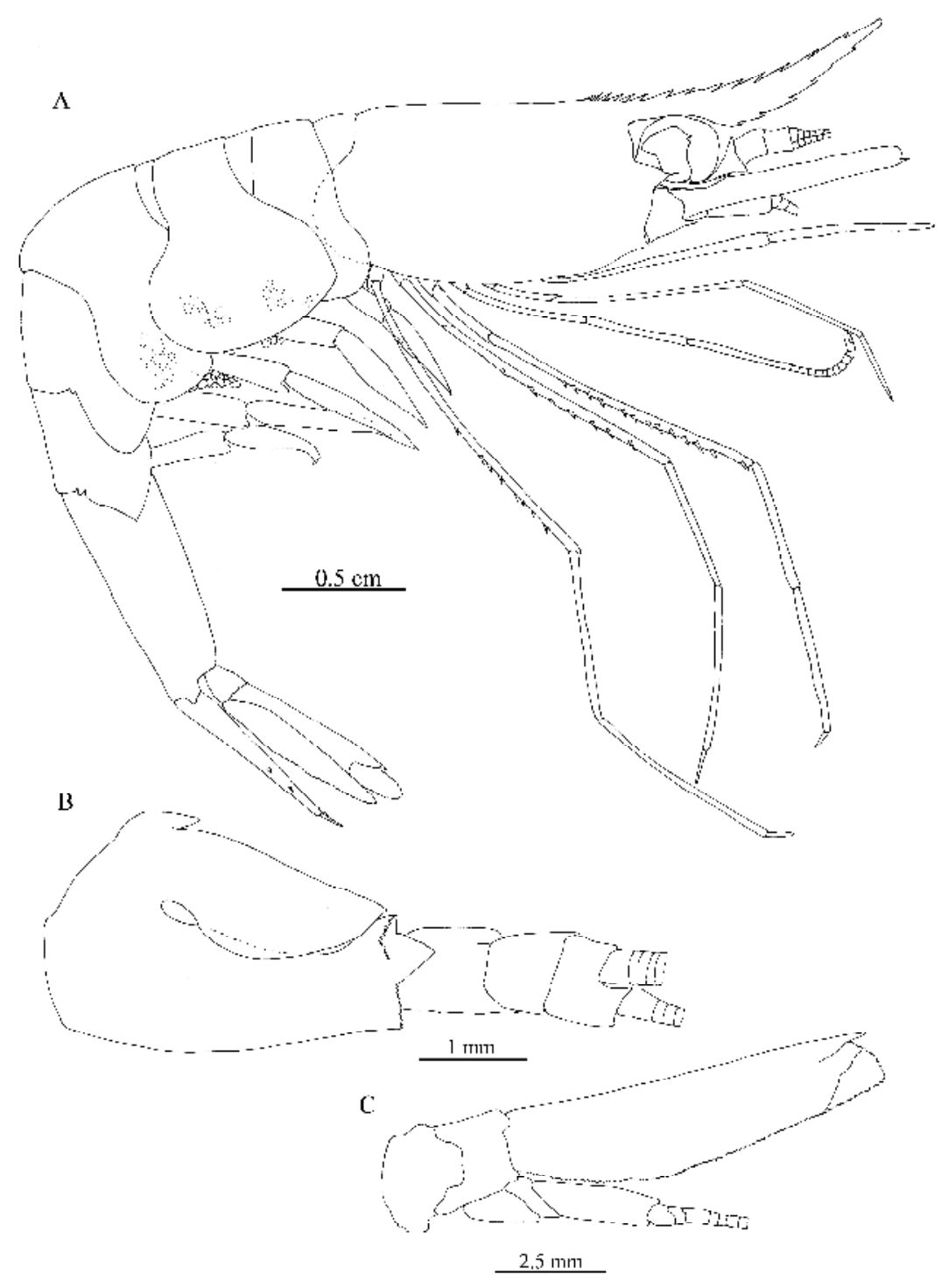

Figure 1 - Plesionika acanthonotus (Smith, 1882), ovigerous female, MNRJ 14664 (carapace length $11.7 \mathrm{~mm}$ ); A, lateral view; B, left antennule, dorsal view; C, left scaphocerite, dorsal view (as, antennal spine; ps, pterygostomian spine; st, stylocerite). 

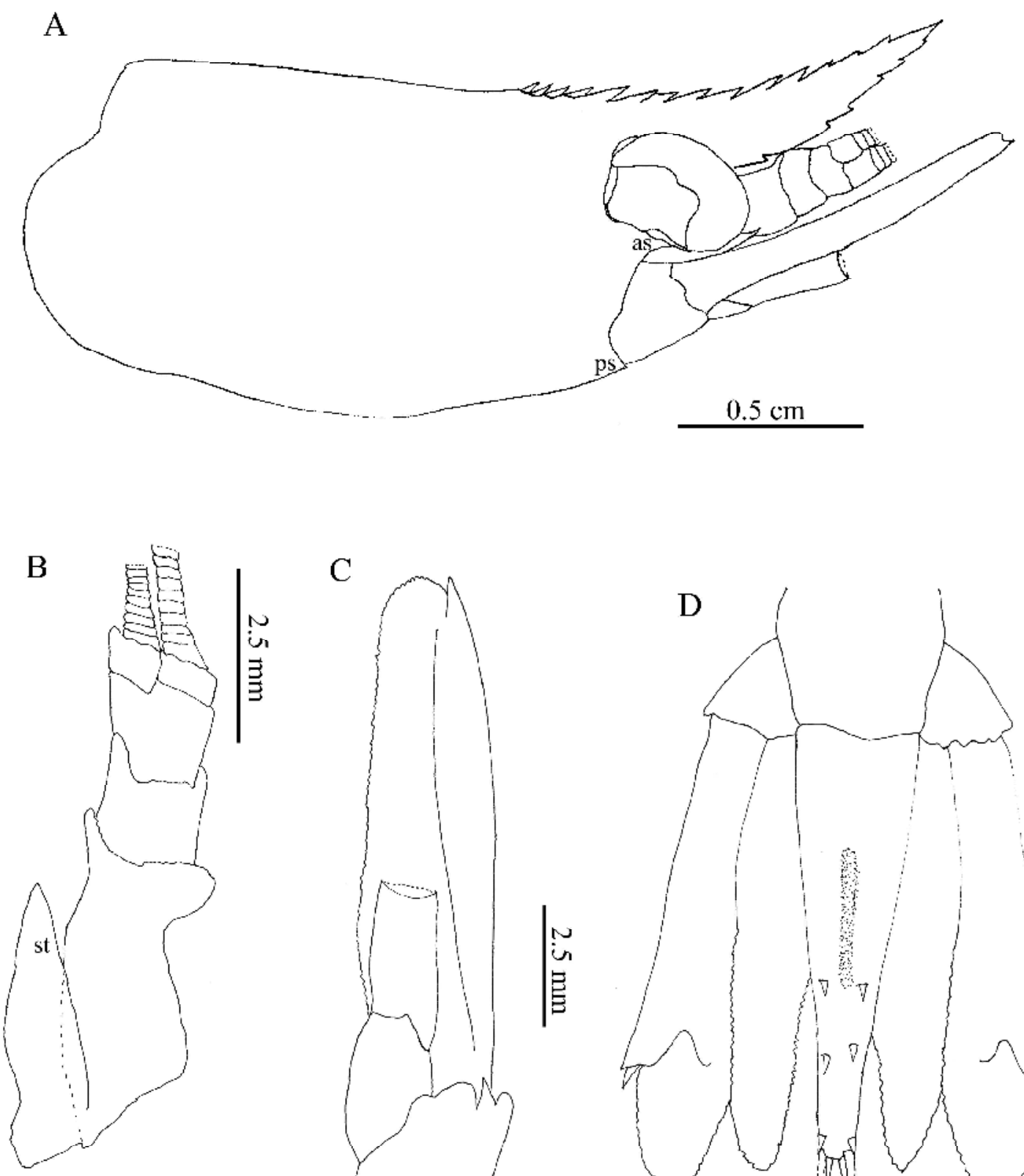

$\mathrm{C}$

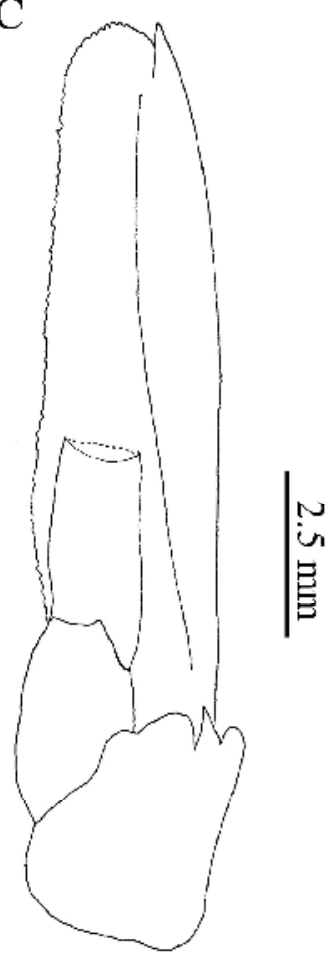

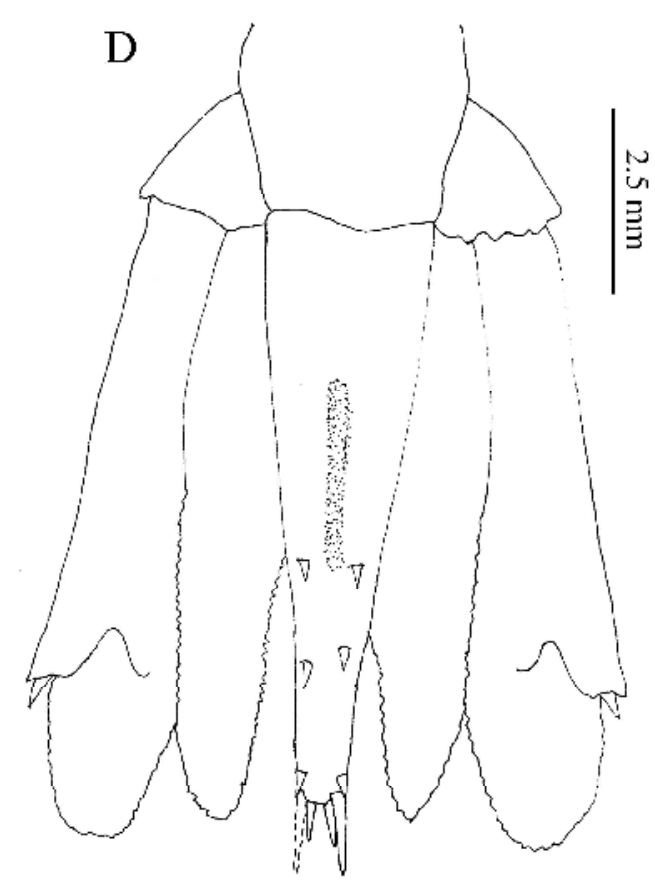

Figure 2 - Plesionika acanthonotus (Smith, 1882), ovigerous female, MNHN 3860 (carapace length $14 \mathrm{~mm}$ ); A, lateral view; D, telson and uropods. Ovigerous female (carapace length $14.5 \mathrm{~mm}$ ); B, left antennule, dorsal view; C, left scaphocerite, dorsal view (as, antennal spine; ps, pterygostomian spine; st, stylocerite). 

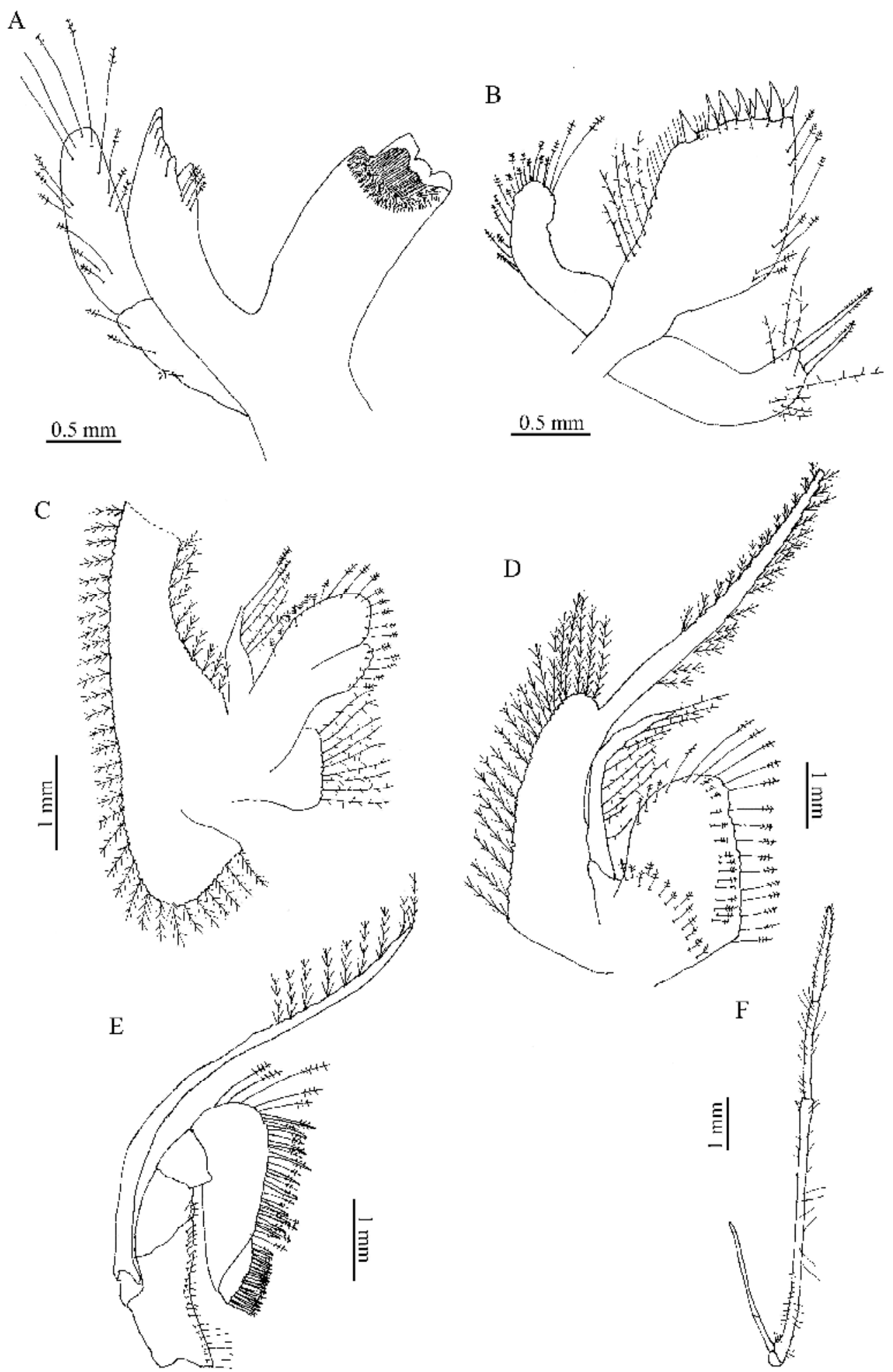

Figure 3 - Plesionika acanthonotus (Smith, 1882), ovigerous female, MNRJ 14664 (carapace length 11.7mm); A, left mandible, dorsal view; B, left maxillule, dorsal view; C, left maxilla, dorsal view; D, left maxilliped 1, dorsal view; E, left maxilliped 2, dorsal view; F, left maxilliped 3, dorsal view. 


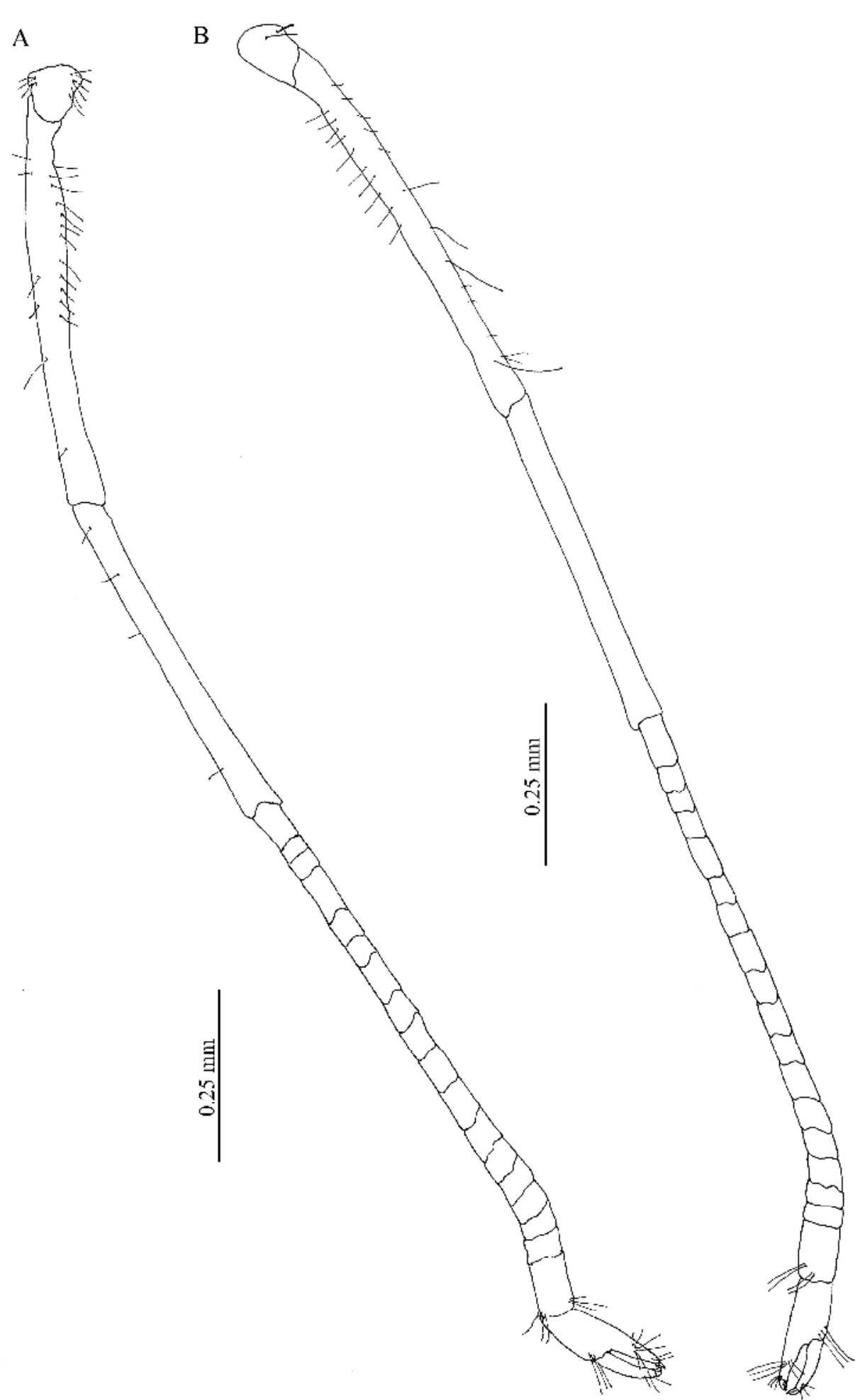

Figure 4 - Plesionika acanthonotus (Smith, 1882), male, MNRJ 14121 (carapace length $7.5 \mathrm{~mm}$ ); A, right pereopod 2, dorsal view; B, left pereopod 2, dorsal view. 


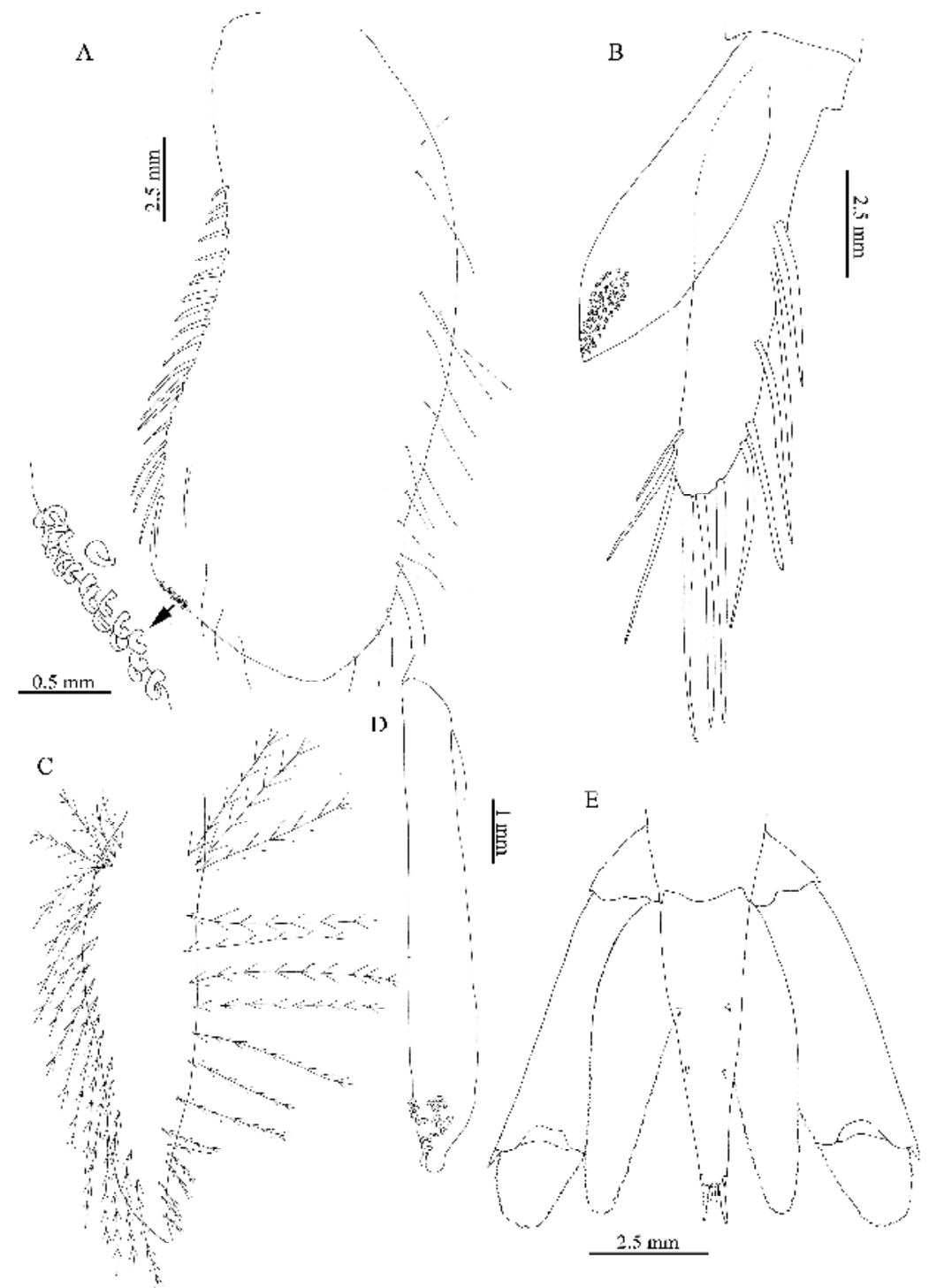

Figure 5 - Plesionika acanthonotus (Smith, 1882), male, MNRJ 12197 (carapace length $10 \mathrm{~mm}$ ); A, endopod of right first pleopod, lateral view; B, appendix interna of right second pleopod, lateral view. Ovigerous female, MNRJ 14664 (carapace length $11.7 \mathrm{~mm}$ ); C, endopod of right first pleopod, lateral view; D, appendix interna of right second pleopod, lateral view; E, telson and uropods, dorsal view.

Pandalus acanthonotus Smith, 1882: 61.

Pandalus Parfaitii A. Milne Edwards, 1883: 21; De Man, 1920: 107.

Pandalus geniculatus A. Milne Edwards, 1883: 25; Coutière: 1905: 675.

Nothocaris geniculatus - Bate, 1888: 661; Moreira, 1901: 8.

Plesionika geniculata - De Man, 1920: 106

Plesionika acanthonotus - De Man, 1920: 105; Holthuis, 1951: 62; Crosnier \& Forest, 1968: 661; Pequegnat, 1970: 91; Omori, 1971: 241; Kensley, 1972; 50; Crosnier \& Forest, 1973: 203; Cruz \& Fransen, 2004: 132.

Material examined: REVIZEE: D-0502, $\quad 14^{\circ} 36^{\prime} \mathrm{S}, 38^{\circ} 52^{\prime} \mathrm{W}, 740 \mathrm{~m}, 1 \mathrm{male}(10.3 \mathrm{~mm}), 1$ female $19^{\circ} 37^{\prime} \mathrm{S}, 38^{\circ} 41^{\prime} \mathrm{W}, 706 \mathrm{~m}, 2$ males $(7.5,14.5 \mathrm{~mm}), 3$ females $(8-16 \mathrm{~mm}), 1$ ovigerous female $(9 \mathrm{~mm})$, MNRJ 14121; D- 0503, 19³9'S, 38 $38^{\circ} \mathrm{W}, 808 \mathrm{~m}, 1$ male $(11 \mathrm{~mm}), 1$ female $(9.9 \mathrm{~mm}), 9$ ovigerous (10.5 mm), 3 ovigerous females (10.3-13.4 mm), MNRJ 14664. Muséum National d'Histoire Naturelle: ORSTOM, st. $5,14^{\circ} 01^{\prime} \mathrm{N}, 17^{\circ} 31^{\prime} \mathrm{W}, 360 \mathrm{~m}, 2$ ovigerous females $(14,14.5 \mathrm{~mm})$, MNHN 3860 . 
Diagnosis: Rostrum relatively short, once or less than once carapace length, not overreaching scaphocerite; ventral margin with six to nine teeth, dorsal margin with four to six stout setae before ocular peduncle and nine to 12 teeth after ocular peduncle; strong antennal and small pterygostomian spines present. Abdominal somites without small posteromesial tooth; abdominal somite 6 more than three times as long as high. Pereopods 2 with same size, carpus with 17 to 21 articles. Male pleopod 1 with oval endopod, posterior margin with simple setae, anterior margin with short stout setae, distal margin with a cluster of hook setae. Male pleopod 2 appendix interna, almost as long as appendix masculina, distal portion triangular, with hook setae; appendix masculina with strong acute simple setae on distal and anterior margins.

Description: Rostrum short, strongly directed upwards, once or less than once carapace length, not overreaching scaphocerite; ventral margin with six to nine teeth, dorsal margin with four to six stout setae before ocular peduncle and nine to 12 teeth after ocular peduncle; strong antennal and small pterygostomian spines present. Carapace (Figs. 1A, 2A) dorsal margin not carinate anteriorly; strong antennal and small pterygostomian spines present; carapace smooth, without carinae. Stylocerite (Figs. 1B, 2B) broad at base, inner margin convex, outer margin almost straight, tapering in a sharp tip, reaching the distal margin of first antennular peduncle article. Scaphocerite (Figs. 1C, 2C) with rounded apex, distal tooth reaching blade's end and plumose setae on inner margin. Mandible (Fig. 3A) with palp three-articulated, incisor process with about seven teeth, molar process with three rounded teeth, a row of small grooves and tufts of small simple setae forming a brush. Maxillule (Fig. 3B)with two endites, distal endite with numerous stout setae on inner margin; basal endite slender, with pectinate setae on inner margin; palp with some pappose setae and a bifid apex with two pectinate setae. Maxilla (Fig. 3C) with two endites, distal endite bilobed with long pectinate setae on inner margin; basal endite with pappose setae on a straight inner margin; endopod with pectinate and pappose setae on apex and inner margin; scaphognathite with densely plumose setae on all margins. Maxilliped 1 (Fig. 3D), endite with slender pectinate setae on inner margin; endopod overreaching anterior margin of distal endite, with pappose setae on apex and inner margin; exopodal lobe with plumose setae in outer margin and plumose articulated setae on apex; exopod long, once and one fourth as long as exopodal lobe, with plumose articulated setae on all margins. Maxilliped 2 (Fig. 3E) endopod with simple setae on ischium and merus inner margins; carpus short; propod elongate with stout and slender pectinate setae on inner margin; dactyl small with stout and slender pectinate setae on inner margin; elongate exopod, with plumose articulated setae on all margins. Maxilliped 3 (Fig. 3F)slender and elongate, ischium-merus with simple setae on inner margin; propod-dactyl with short plumose setae on all margins; exopod slender and elongate. Pereopod 1 simple. Pereopod 2 (Fig. 4) chelate with same size, carpus with 18 articles. Abdominal somites (Fig. 1A) without posteromesial tooth; abdominal somite 6 more than three times as long as high. Male pleopod 1 (Fig. 5A) with oval endopod, posterior margin with simple setae, anterior margin with short stout setae, distal margin with a cluster of hook setae. Male pleopod 2 (Fig. 5B) appendix interna, almost as long as appendix masculina, distal portion triangular, with hook setae; appendix masculina with strong acute simple setae on distal and anterior margins. Female pleopod 1 (Fig. $5 \mathrm{C}$ ) with endopod leaf like bearing plumose setae in all margin. Female pleopod 2 (Fig. 5D) appendix interna with triangular apex bearing hook setae. Exopod of uropod (Figs. 5E, 2D) with complete diaresis, with one distal stout setae on outer margin. Telson (Figs. 5E, 2D) not sulcate in anterior dorsal midline, with three pairs of dorsolateral stout setae, and two pairs of stout distal setae.

Distribution: Western Atlantic: USA (South Caroline, Florida), Mexico (Gulf of Mexico), Brazil (Pará, Pernambuco, Bahia e Espírito Santo). Eastern Atlantic: Portugal, Spain, Congo, Angola. Mediterranean. Adults are benthic, living in depths from 190 meters to $1350 \mathrm{~m}$ (modified from Crosnier \& Forest 1973).

Plesionika holthuisi Crosnier \& Forest, 1968 


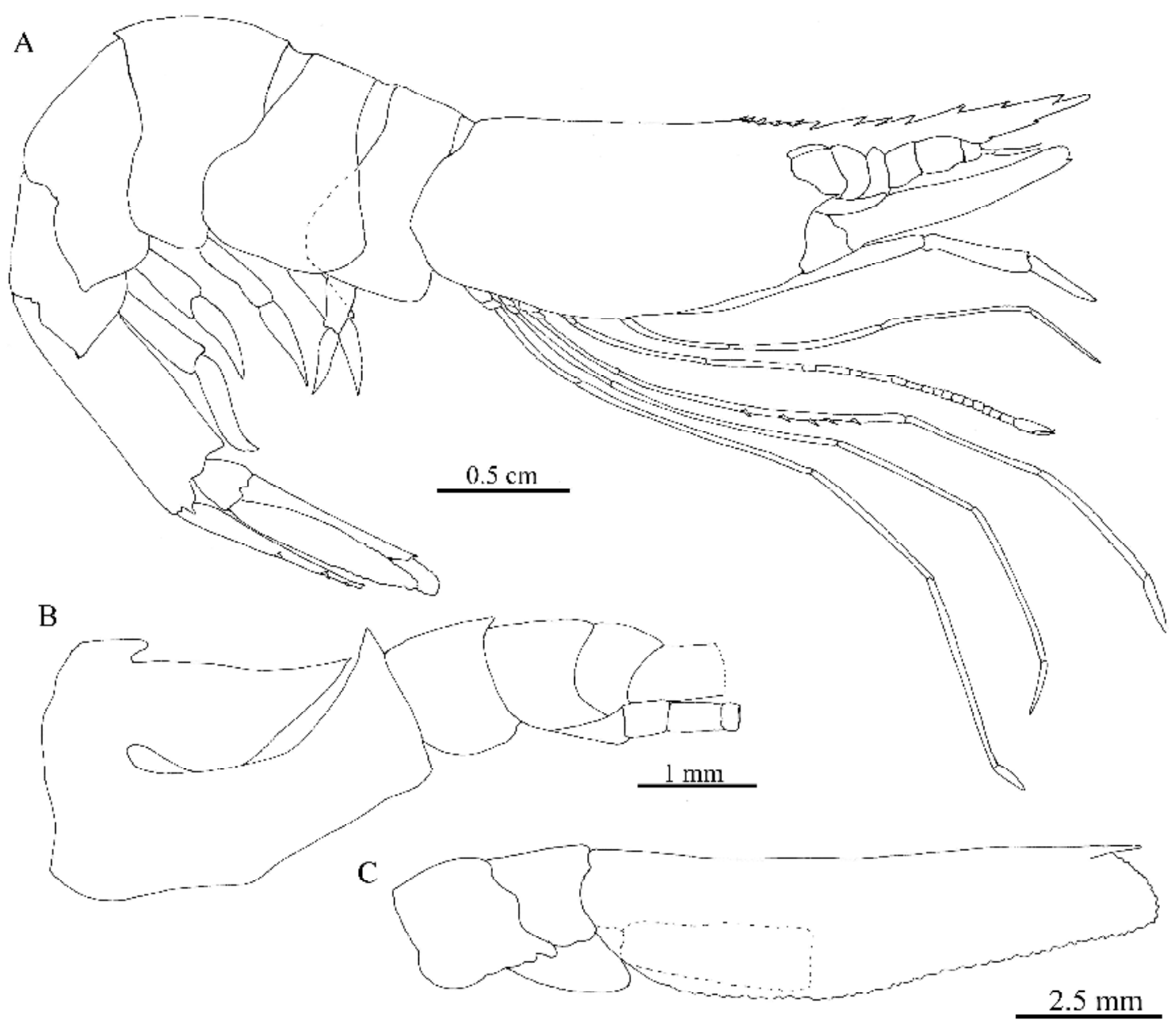

Figure 6 - Plesionika holthuisi Crosnier \& Forest, 1968, male, MNRJ 19429 (carapace length 12 mm); A lateral view; B, left antennule, dorsal view; C, left scaphocerite, dorsal view (as, antennal spine; ps, pterygostomian spine; st, stylocerite). 

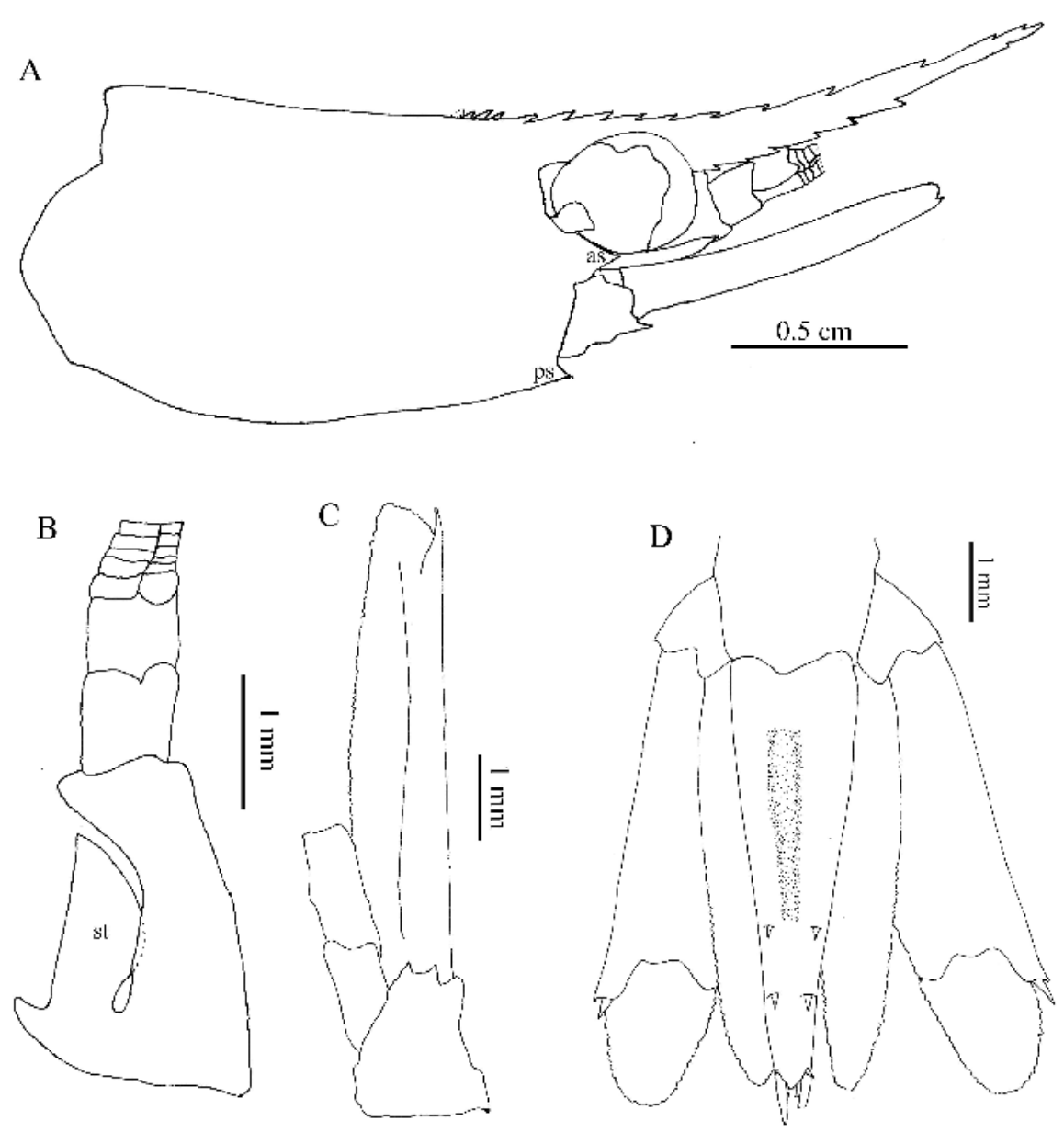

Figure 7 - Plesionika holthuisi Crosnier \& Forest, 1968, ovigerous female, MNHN 2070 (carapace length 13.2 mm); A lateral view; B, left antennule, dorsal view; C, left scaphocerite, dorsal view (as, antennal spine; ps, pterygostomian spine; st, stylocerite); D, telson and uropods. 


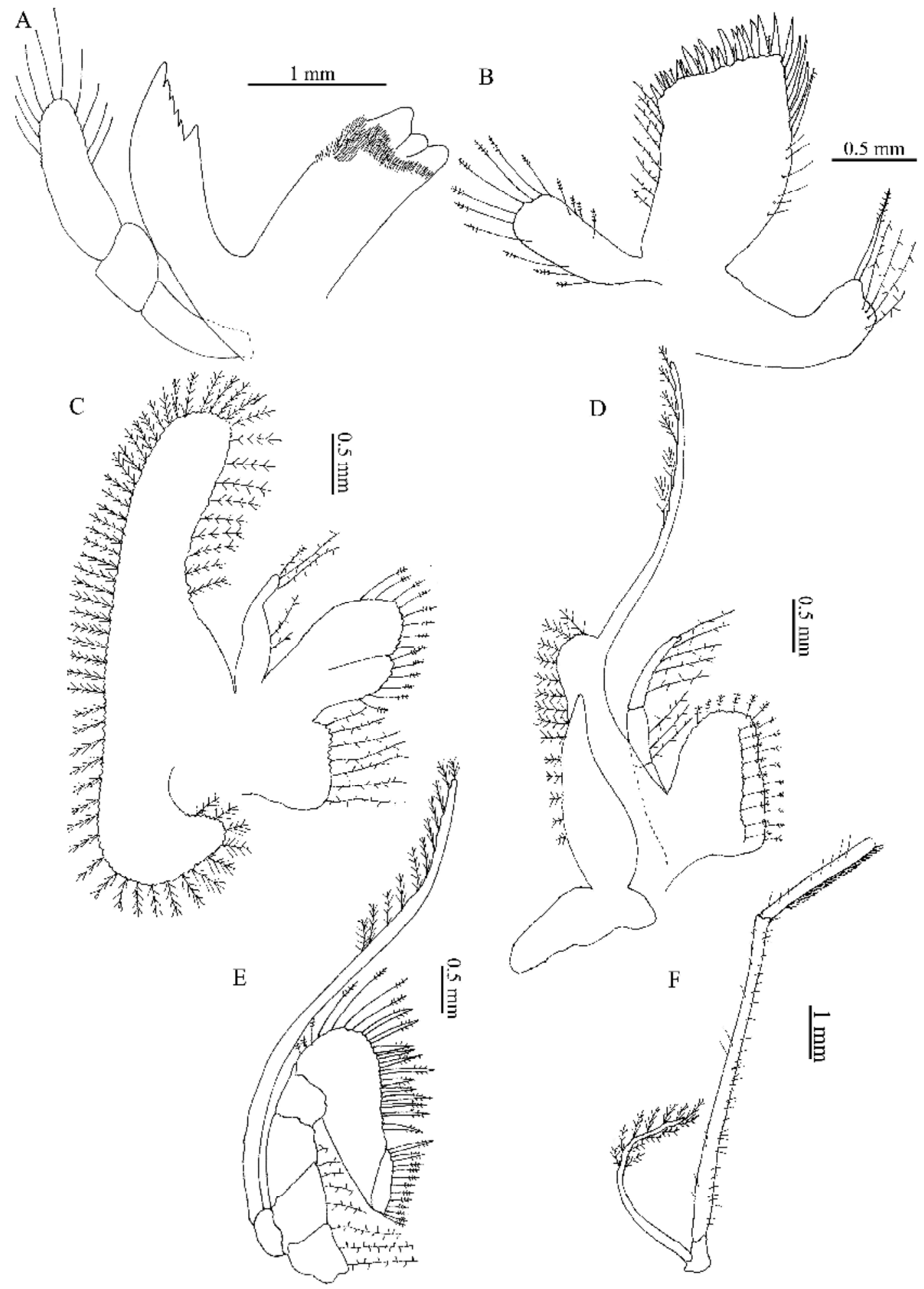

Figure 8 - Plesionika holthuisi Crosnier \& Forest, 1968, ovigerous female, MNRJ 19429 (carapace length $10 \mathrm{~mm}$ ); $A$, left mandible, dorsal view; B, left maxillule, dorsal view; $C$, left maxilla, dorsal view; $D$, left maxilliped 1, dorsal view; E, left maxilliped 2, dorsal view; F, left maxilliped 3, dorsal view. 


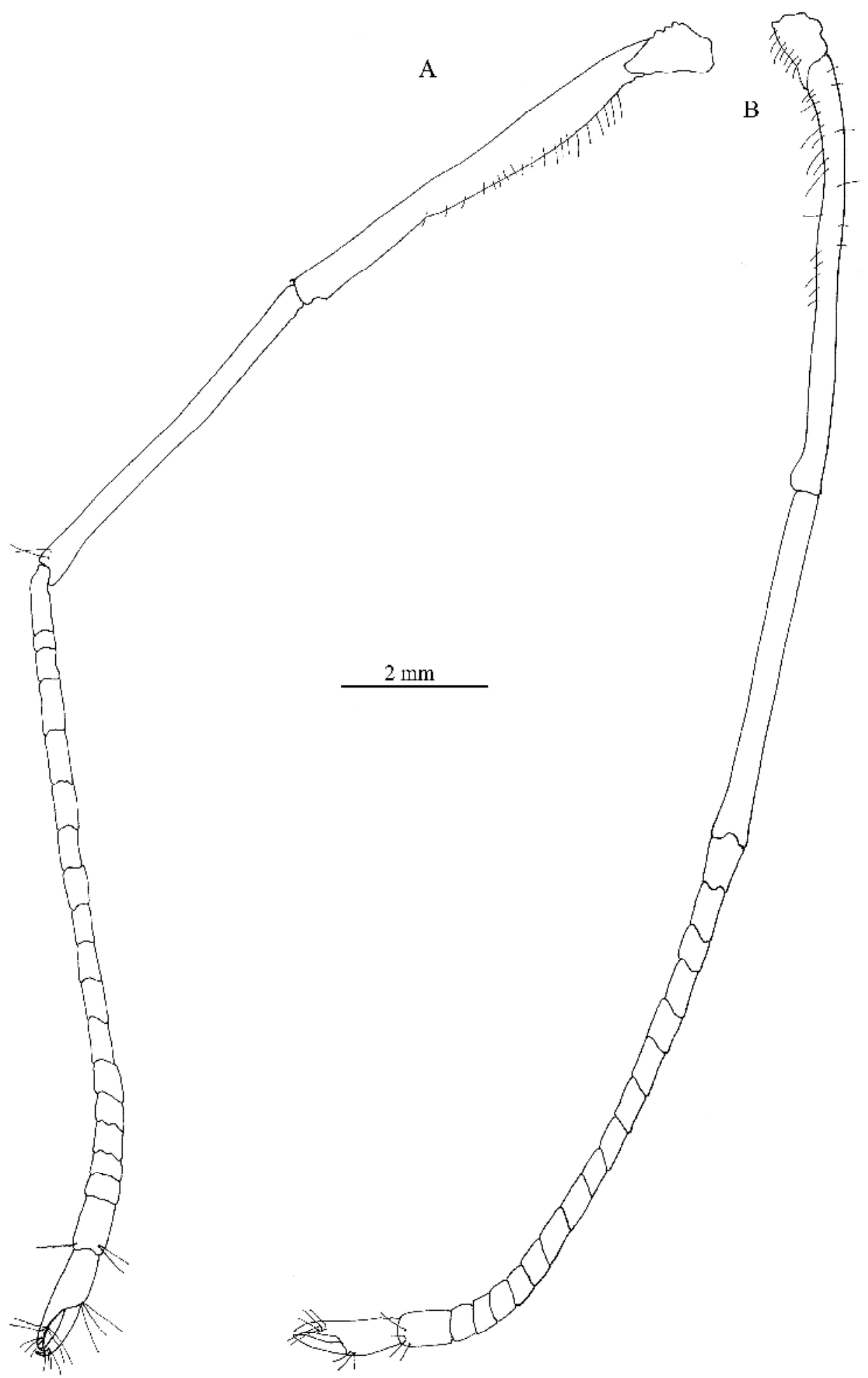

Figure 9 - Plesionika holthuisi Crosnier \& Forest, 1968, ovigerous female, MNRJ 19429 (carapace length $10 \mathrm{~mm}$ ); A, right pereopod 2, dorsal view; B, left pereopod 2, dorsal view. 


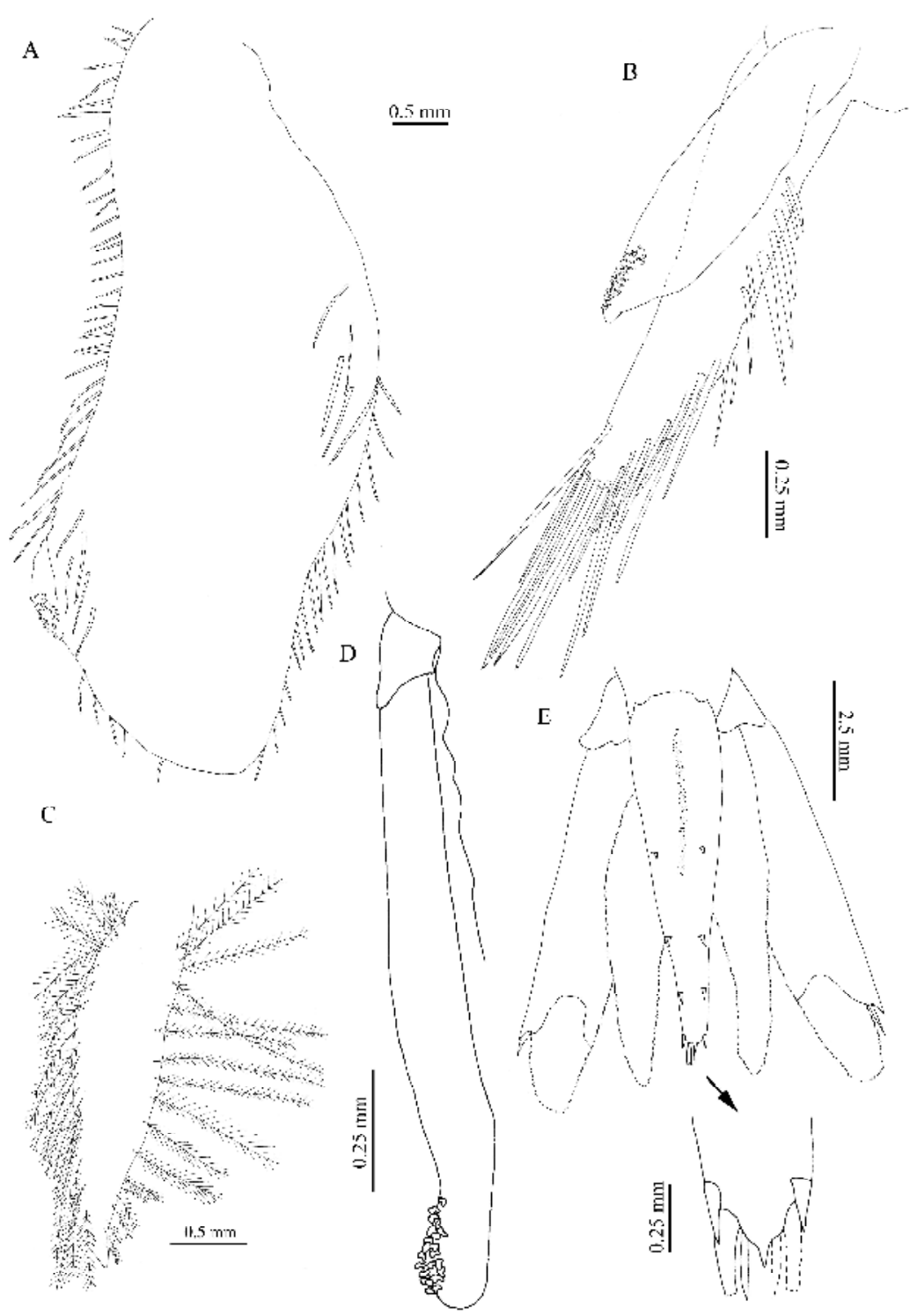

Figure 10 - Plesionika holthuisi Crosnier \& Forest, 1968, male, MNRJ 19429 (carapace length 12 mm); A, endopod of right first pleopod, lateral view; B, appendix interna of right second pleopod, lateral view; E, telson and uropods, dorsal view. Ovigerous female, MNRJ 19429 (carapace length $10 \mathrm{~mm}$ ); C, endopod of right first pleopod, lateral view; D, appendix interna of right second pleopod, lateral view.

Plesionika acanthonotus - Holthuis, 1951: 62 (part); 1952: 36, fig. 9 (part).

Plesionika holthuisi Crosnier \& Forest, 1968: 1141, fig. 7b, c; 1973: 206, fig. 64c, 65b-d;

Pequegnat, 1970: 94, fig. 4-12; Omori, 1971: 241.

Material examined: REVIZEE: D-0502, $19^{\circ} 37^{\prime} \mathrm{S}, 38^{\circ} 41^{\prime} \mathrm{W}, 706 \mathrm{~m}, 23$ males (9.6-16.0 mm), 7 females (11.6-16.6 mm), 16 ovigerous females (9.4$13.8 \mathrm{~mm}$ ), MNRJ 21430; D- 0503, 19 $39^{\circ} \mathrm{S}, 38^{\circ} 38^{\prime} \mathrm{W}$, $808 \mathrm{~m}, 59$ males (10-13.4 mm), 19 females (9.3-13.4 $\mathrm{mm}), 79$ ovigerous females (10-15 mm), MNRJ 19429; E- $0503,14^{\circ} 36^{\prime} \mathrm{S}, 38^{\circ} 52^{\prime} \mathrm{W}, 740 \mathrm{~m}, 7$ ovigerous females (10-11.7 mm), MNRJ 21429. Muséum National d'Histoire naturelle: OMBANGO, $5^{\circ} 30^{\prime} \mathrm{S}$, $11^{\circ} 32^{\prime} \mathrm{E}, 505 \mathrm{~m}, 1$ ovigerous female $(13.2 \mathrm{~mm})$, MNHN 2070.

Diagnosis: Rostrum relatively short, slightly longer than carapace, reaching or overreaching scaphocerite; ventral margin with seven teeth, dorsal margin with three to six stout setae before ocular peduncle and seven to 11 teeth after ocular peduncle; strong antennal and small pterygostomian spines 
present. Abdominal somite 3 with small posteromesial tooth; abdominal somite 6 more than three times as long as high. Pereopods 2 with same size, carpus with 18 to 19 articles. Male pleopod 1 with oval endopod, posterior margin with simple setae, anterior margin with short stout setae, distal margin with a cluster of hook setae. Male pleopod 2 appendix interna, more than a half of appendix masculine length, distal portion triangular, with hook setae; appendix masculina with strong acute simple setae on distal and anterior margins.

Description: Rostrum short, slightly directed upwards, slightly longer than carapace, reaching or overreaching scaphocerite; ventral margin with seven teeth, dorsal margin with three to six stout setae before ocular peduncle and seven to 11 teeth after ocular peduncle; strong antennal and small pterygostomian spines present. Carapace (Figs. 6A, 7A) dorsal margin not carinate anteriorly; carapace smooth, without carinae. Stylocerite (Figs. 6B, 7B) broad at base, inner margin convex, outer margin slightly concave, tapering in a sharp tip, not reaching the distal margin of first antennular peduncle article. Scaphocerite (Figs. 6C, 7C) with rounded apex, distal tooth reaching blade's end and plumose setae on inner margin. Mandible (Fig. 8A) with palp threearticulated, incisor process with about six teeth, molar process with three rounded teeth, and tufts of small simple setae forming a brush. Maxillule (Fig. 8B) with two endites, distal endite with numerous stout and short pectinate setae on inner margin; basal endite slender, with pectinate setae on inner margin; palp with some pappose setae and one pectinate setae at a not bifid apex. Maxilla (Fig. 8C) with two endites, distal endite bilobed with long pectinate setae on inner margin; basal endite bilobed with pappose setae on a straight inner margin; endopod with pappose and pappose-pectinate setae on inner margin and apex; scaphognathite with densely plumose setae on all margins. Maxilliped 1 (Fig. 8D) endite with slender pectinate setae on inner margin; endopod three articulated, overreaching anterior margin of distal endite, with pappose setae on apex and inner margin; exopodal lobe with plumose setae in outer margin; exopod long, once and one fourth as long as exopodal lobe, with plumose articulated setae on all margins.
Maxilliped 2 (Fig. 8E) endopod with simple setae on ischium and merus inner margins; carpus short; propod elongate with stout and slender pectinate setae on inner margin; dactyl small with stout and slender pectinate setae on inner margin; elongate exopod, with plumose articulated setae on all margins. Maxilliped 3 (Fig. 8F) slender and elongate, ischiummerus with simple setae on inner margin; propoddactyl with short plumose setae on all margins; exopod slender and elongate. Pereopod 1 simple. Pereopod 2 (Fig. 9) chelate with same size, carpus with 18 articles. Abdominal somite 3 with small posteromesial tooth; abdominal somite 6 more than three times as long as high (Fig. 6A). Male pleopod 1 (Fig. 10A) with oval endopod, posterior margin with simple setae, anterior margin with short stout setae, distal margin with a cluster of hook setae. Male pleopod 2 (Fig. 10B) appendix interna, more than a half of appendix masculine length, distal portion triangular, with hook setae; appendix masculina with strong acute simple setae on distal and anterior margins. Female pleopod 1 (Fig. 10C) with endopod leaf like bearing plumose setae in all margin. Female pleopod 2 (Fig. 10D) appendix interna slender with rounded apex bearing stout setae. Exopod of uropod (Figs. 10E, 7D) with complete diaresis, with one distal stout setae on outer margin. Telson (Figs. 10E, 7D) sulcate in anterior dorsal midline, with four pairs of dorsolateral stout setae, the anterior one small, and two pairs of stout distal setae.

Distribution: Western Atlantic: Mexico (Gulf of Mexico), Brazil (Bahia and Espírito Santo). Eastern Atlantic: Senegal, Congo, Angola. Adults are benthic, living in depths from 480 to $800-900 \mathrm{~m}$ (Crosnier \& Forest, 1973).

\section{DISCUSSION}

In 1951, with a material from the African coast, Holthuis (1951) identified two specimens as Plesionika acanthonotus variations; they were bad preserved, but present an unusual long rostrum. The same author in 1952 described another specimen in the same way (longer rostrum, but bad preserved) and affirms that a more abundant material was necessary to get in some clear conclusion about these specimens. 
Crosnier \& Forest (1968), based on an abundant material collected in African coast, confirmed Holthuis $(1951 ; 1952)$ idea, that these variations represent a new Plesionika species, and first described $P$. holhuisi. They gave the species name in honor of who first observed the differences between $P$. acanthonotus and $P$. holthuisi, two very close related species.

Cruz \& Fransen (2004) affirms that morphological features do not provide reliable characters to clear the relations between the various Atlantic populations of these species. However in their comments Crosnier \& Forest $(1968 ; 1973)$ affirms that $P$. holthuisi differs from $P$. acanthonotus mainly in having: a longer rostrum overreaching scaphocerite; a larger eye and a shorter third maxilliped. In the Brazilian material few specimens of $P$. holthuisi present a short rostrum and it doesn't overreaches scaphocerite, in these specimens the rostrum just reaches scaphocerite apex. In spite of that, these two species can be separated by some other differences

\section{ACKNOWLEDGEMENTS}

The author would like to acknowledge the staff of Département Milieux et Peuplements Aquatiques (Muséum National

\section{REFERENCES}

BATE, CS. 1888. Report on the Crustacea Macrura collected by the Challenger during the years 1873-76. Rep. Voy. Challenger, Zool., 24: 1-942.

CABRAL, E., M. RAMOS-PORTO, M. ACIOLI, M. TORRES \& G. VIANA. 2000. Shrimps collected in the Northeast of Brazil during the REVIZEE Program (Decapoda: Caridea). Nauplius, 8(2): 245-248.

CARDOSO, IA. 2009. Report on some Plesionika Bate, 1888 and first record of Stylopandalus Coutiére, 1905 (Caridea, Pandalidae) from Brazilian waters. Zootaxa, 2120: 53-68.

CHACE, FA. 1985. The caridean shrimps (Crustacea: Decapoda) of the Albatross Philippine Expedition, 1907-1910, Part 3: Families Thalassocarididae and Pandalidae. Smith. Contr. Zool., 411, p: 1-143.

COUTIĖRE, H. 1905. Note préliminaire sur les eucyphotes recueillis par S.A.S. le prince de Monaco à l'aide du filet à grande ouverture (campagnes de la "Princesse Alice" 19031904). Bull. Mus. océanogr. Monaco, 48: 1-35.

CROSNIER, A \& J FOREST. 1968. Note préliminaire sur les carides recueillis par l'Ombango au large du plateau continental, du Gabon à l'Angola (Crustacea Decapoda Natantia). Bull. Mus. Hist. nat. Paris, ser. 2, 39 (6): 1123-1147.

CROSNIER, A \& J FOREST. 1973. Les crevettes profondes de l'Atlantique oriental tropical. Faune Tropicale, 19: 1-409.

CRUZ, N. \& CH. FRANSEN. 2004. Addition of three species of the observed herein. In $P$. holthuisi the rostrum is slightly directed upwards while in $P$. acanthonotus it is strongly directed upwards. Unlike $P$. acanthonotus, $P$. holthuisi presents: ventral margin with seven teeth, dorsal margin with three to six stout setae before ocular peduncle and seven to 11 teeth after ocular peduncle; pereopod 2 carpus with 18 or 19 articles and appendix interna, more than a half of appendix masculina length. In the abdominal somite $3 P$. holthuisi presents a small posteromesial tooth that is absent in $P$. acanthonotus. Besides that, in $P$. holthuisi the telson is dorsally sulcate, with four dorsolateral stout setae, while in $P$. acanthonotus it is not sulcate and there are three pairs of dorsolateral stout setae.

Considering the differences cited above, we can conclude that these two species are valid, however they are very close related and their identification can be complex, mainly if you don't have previously identified samples of the two species to compare.

d'Histoire Naturelle-MNHN) for the attention during my studies on Plesionika collection, and to Petrobras for the fellowship.

Ramos-Porto \& Coelho 1998; Cabral et al. 2000; Viana et al. 2007; Cardoso 2009; Cruz \& Fransen

genus Plesionika (Crustacea: Caridea: Pandalidae) to the known Atlantic marine fauna of Colombia. Zoologische Mededelingen, 78: 131-146.

DE MAN, JG. 1920. The Decapoda of the Siboga Expedition, IV: Families Pasiphaeidae, Stylodactilidae, Hoplophoridae, Nematocarcinidae, Thalassocaridae, Pandalidae, Psalidopodidae, Gnathophylidae, Processidae, Glyphocrangonidae, and Crangonidae. Siboga-Exped., 39a (3): 1-318.

GARM, A. 2004. Revising the definition of the crustacean seta and setal classification systems based on examinations of the mouthpart setae of seven species of decapods. Jour. Linn. Soc. London,. 142: 233-252.

HOLTHUIS, LB. 1951. The caridean Crustacea of Tropical West Africa. Atlantide Rep., 2:. 7-187.

HOLTHUIS, LB. 1952. Crustacés Décapodes Macrures. Résultats scientifiques de la Expedition océanographique belge Eaux côtiéres africanes, Atlantico Sud (1948-1949), 3 (2): 1-88.

KENSLEY, B., HA. TRANTER \& DJG. GRIFFIN. 1987. Deepwater decapod from eastern Australia (Penaeidea and Caridea). Rec. Austr. Mus., 39: 263-331.

MARTIN, J \& G DAVIS. 2001. An updated classification of the Recent Crustacea. Natural History Museum of Los Angeles County, Science Series, 39: 1-124.

MCLAUGHLIN, PA 1980. Comparative Morphology of Recent Crustacea. San Francisco, W H. Freeman and Company, 177p.

MILNE-EDWARDS, A. 1883. Recueil de figures de crustacés 
nouveaux ou peu connus, Paris, $3 \mathrm{p}, 44 \mathrm{pl}$.

MOREIRA, C. 1901. Crustáceos do Brasil. Contribuição para o conhecimento da fauna brasileira. Arq. Mus. Nac., 11: 1-151.

OMORI, M. 1971. Taxonomy and some notes on the biology of a new caridean shrimp, Plesionika izumiae (Decapoda, Pandalidae). Crustaceana, 20 (3): 241-256.

PEQUEGNAT, LH. 1970. Deep Sea Caridean shrimps with description of six new species. Texas A \& M University Oceanographic Studies. I. Contributions on the biology of the Gulf of Mexico, 4: 59-123.

RAMOS-PORTO, M. \& P COELHO. 1988. Malacostraca. Eucarida. Caridea (Alpheoidea excluded), In: YOUNG, PS (ed.) Catalogue of Crustacea of Brazil, Rio de Janeiro, Museu Nacional, Série Livros, 6: 325-350.

SMITH, SI. 1882. Report on Crustacea. Part I. Decapoda. Reports on the results of dredging, under the supervision of Alexander Agassiz, on the east coast of the United States, during the summer of 1880 , by the U. S. coast survey steamer "Blake", commander J. R. Barlett, U. S. N., commanding. Bull. Mus. comp. Zool. Harvard, 10: 1-108.

VIANA G., M. RAMOS-PORTO, M. TORRES \& M. SANTOS. 2007. Distribution of Heterocarpus laevigatus Bate, 1888 and Plesionika escatilis (Stimpson, 1860) along the Atlantic coast of South America (Crustacea: caridea: Pandalidae). Zootaxa, 1577: 33-39.

WATLING, LA 1989. Classification system for crustacean setae based on the homology concept. In: FELGENHAUER, BE, ABTHISTLE \& L WATLING (eds.) Functional morphology of feeding and grooming in Crustacea. Crustacean Issues, 6: 1526.

Recebido: 10/10/2008

Aceite: 04/08/2010 
